Case report

\title{
INTERMITTENT GASTROESOPHAGEAL INTUSSUSCEPTION IN A KITTEN RESOLVED WITH A PERCUTANEOUS GASTROPEXY
}

\author{
DEL-ANGEL-CARAZA Javier*, ALVAREZ-CONTRERAS Paolo Cesar, \\ BARBOSA-MIRELES Marco Antonio, QUIJANO-HERNÁNDEZ Israel Alejandro
}

Hospital Veterinario para Pequeñas Especies, Facultad de Medicina Veterinaria y Zootecnia, Universidad Autónoma del Estado de México. Jesús Carranza 203 Col. Universidad, CP 50130 Toluca-México.

(Received 29 January; Accepted 06 May 2016)

Gastroesophageal intussusception is a rare pathology characterized by an acute or intermittent invagination of the stomach into the lumen caudal to the thoracic esophagus, the pathogenesis is not well understood, although it is likely multifactorial. The mortality is high, associated with a late diagnosis and a rapid deterioration. A 4-month-old male domestic shorthair kitten presented for evaluation of intermittent respiratory distress and abdominal discomfort with two weeks of evolution. Based on clinical history, clinical sings and imaging studies a diagnosis of intermittent gastroesophageal intussusception was established. The reduction of the intussusception was performed with endoscopy maneuvers and with medical and nutritional management for some days, but this failed and finally was reduced with a percutaneous gastropexy tube to prevent recurrence with a good long-term outcome. Gastroesophageal intussusception in cats is associated with megaesophagus or hiatal hernia, and should be considered as a differential diagnosis in patients with chronic vomiting, regurgitation or respiratory disease. Survey and contrasted thoracic radiographs can be used to identify gross anatomical abnormalities, but the definitive diagnosis should be made by esophagogastroscopy with the possibility of reducing the intussusception. The use of percutaneous gastropexy provides other possible option to conventional surgery for the management of this pathology in cats.

Key words: cat, gastroesophageal intussusception, megaesophagus, percutaneous gastropexy.

\section{INTRODUCTION}

Esophageal diseases in cats represent 0.05 to $1 \%$ of cases referred to veterinary hospitals [1,2]. Until 2014, only three case studies on esophageal diseases were published, describing esophageal dysmotility due to different origins as the principal pathology [1-3]; however, none of these studies refers to a gastroesophageal intussusception (GEI), a rare pathology characterized by an invagination of the stomach into the lumen caudal to the thoracic esophagus [4-8].

\footnotetext{
*Corresponding author: e-mail: dlangel@uaemex.mx
} 


\section{CASE PRESENTATION}

A 4 month-old intact male shorthair kitten weighing $1.2 \mathrm{~kg}$, that had been adopted two weeks earlier, presented at our hospital with history an intermittent respiratory distress after eating solid food at different times, with a gradual increase in frequency. Upon physical examination, the patient was alert, the body condition score was $2 / 5$, the heart rate was $210 \mathrm{bpm}$ with normal pulse quality, the respiratory rate was 28 breaths per minute with increased respiratory effort, the body temperature was $37.9^{\circ} \mathrm{C}$ and the systemic blood pressure was $140-100 \mathrm{mmHg}$ measured indirectly with a oscillometric monitor (9401 Cardell, USA); other physiological parameters were normal. Routine laboratory testing as hematology, biochemistry profile and urinalysis (IDEXX VetLab suite analyzers, USA) revealed within normal reference intervals, and the result of the feline leukemia virus and immunodeficiency virus assay (FIV Ab/FelLV Ag Test Kit, Anigen Rapid BIONOTE, Inc., Korea) was negative.

Survey thoracic radiographs revealed a large mass of circumscribed soft tissue opacity in the caudodorsal thoracic cavity with a tracheal and heart cranial displacement on the lateral projection. The mass was located at the midline to the left side, extending approximately from the level of the twelfth rib to the diaphragm in the ventrodorsal projection (Figure 1a, b). A positive contrast esophagogram confirmed the intraluminal esophageal obstruction, and the possibility of a GEI (Figure 2a, b).
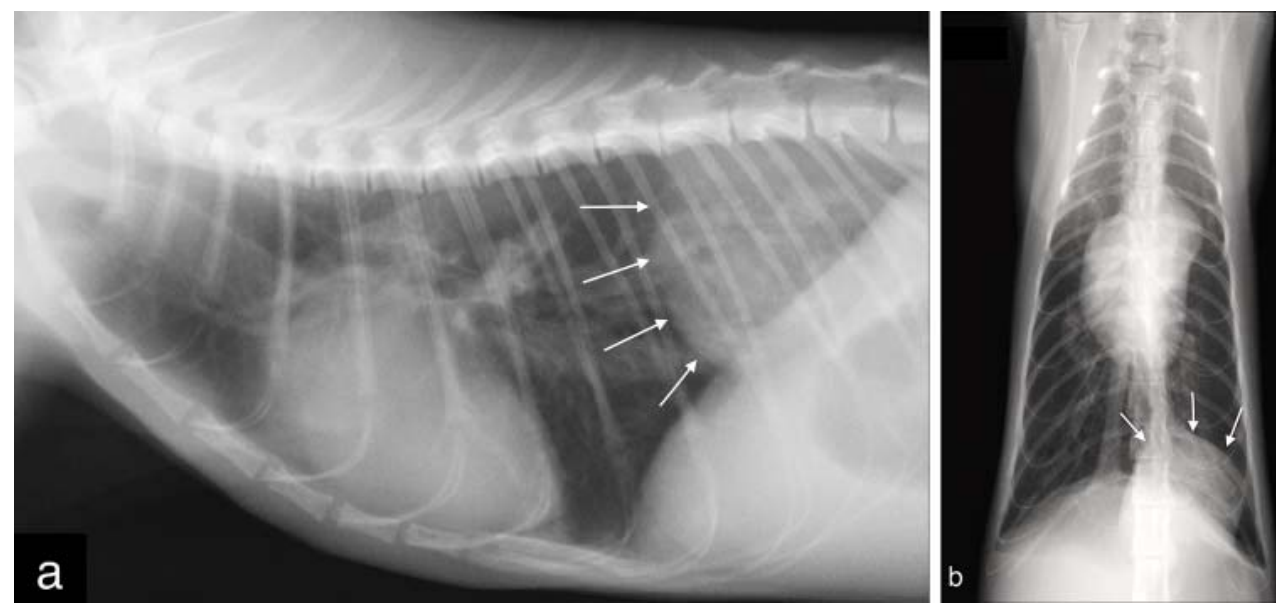

Figure 1. Thoracic radiographic study. (a) The lateral projection revealed a large mass of circumscribed soft tissue opacity in the caudodorsal thoracic cavity, with cranial displacement of the trachea and heart (arrows) and in the ventrodorsal projection (b), the mass was located left of the midline at the level of the twelfth rib to the diaphragm (arrows).

Esophagogastroscopy was performed with a $110 \mathrm{~cm}$ in length and $5.9 \mathrm{~mm}$ insertion tube flexible video endoscope (Video gastroscope, Karl Storz, Germany). The cranial esophagus was normal; caudal esophagus showed dilatation compatible with megaesophagus and esophagitis, the accumulation of intraluminal fluid and 
obstruction by a soft intraluminal tissue mass, which could be identified as the gastric mucosa. Within a few minutes of observation, the portion of the stomach invaginated into the esophageal lumen progressively increased and gradually decreased, but always remained within the esophageal lumen (Figure 3). Uncomplicated reduction of the GEI was achieved by a combination of inflation pressure of the esophagus and gentle advancement of the endoscope according with the technic described by Sherding and Johnson [9]; the gastric mucosa appeared macroscopically intact in the repositioned stomach.
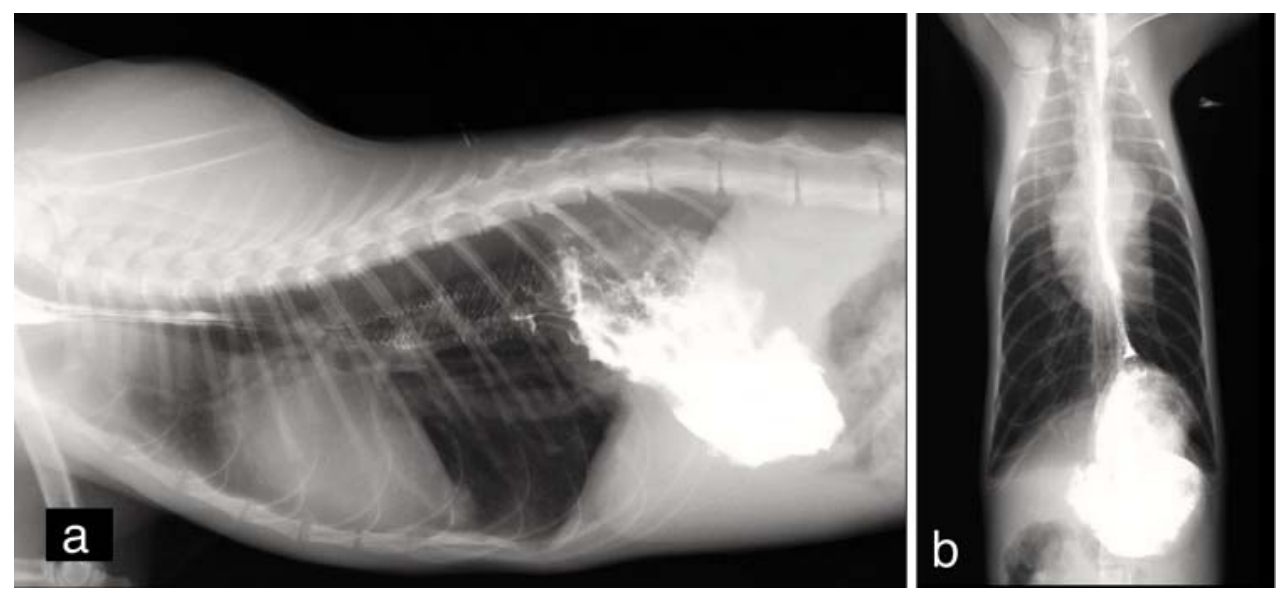

Figure 2. Positive contrast esophagogram (a) lateral and ventrodorsal projection (b), confirming the intraluminal esophageal obstruction and the possibility of a gastroesophageal intussusception.

With a diagnosis of GEI associated with megaesophagus and according to van Geffen et al. [7], we decided to attempt medical management: fluid therapy with maintenance crystalloids, omeprazole, cisapride, and a moist low fat diet (Gastro Intestinal High Energy, Royal Canin, USA) in several meals a day in an upright position. For the next eight days, the patient presented intermittent respiratory distress two to four times per day, both in relation to meals and not, accompanied by cyanosis, syncope and abdominal discomfort. The clinical episodes were managed with oxygen and fluid therapy.

A thoracoabdominal computed tomography scan with contrast was performed and showed a detailed diagnostic image of GEI, without evidence of intussusception of other abdominal anatomical structures (Figure 4).

With the poor outcome of medical and nutritional therapy, surgical correction became necessary. We decide to place a percutaneous gastropexy tube with an 18 Fr Pezzer catheter and fixed the stomach $3 \mathrm{~cm}$ caudal to the thirteenth rib distal to the transverse processes of the lumbar vertebrae on the left abdominal wall; then, with endoscopic inspection, the reduction of the GEI and the gastroesophageal sphincter closed were shown (Fig. 3a). In the stomach, the presence of the mushroom of the Pezzer 
catheter on the gastric wall was shown without hemorrhage (Figure 3b). Post-surgery management was cephalexin (22 $\mathrm{mg} / \mathrm{kg}$ PO BID for two weeks), and buprenorphine $(0.02 \mathrm{mg} / \mathrm{kg}$ PO BID for 5 days).

Twenty-four hours later, the cat was alert and was fed by mouth in a normal position with a moist low fat diet (Gastro Intestinal High Energy, Royal canin, USA) in five meals per day; cisapride (2.5 mg PO TID) and omeprazole were continued. At this point, the patient manifested no clinical signs and was discharged a week later.

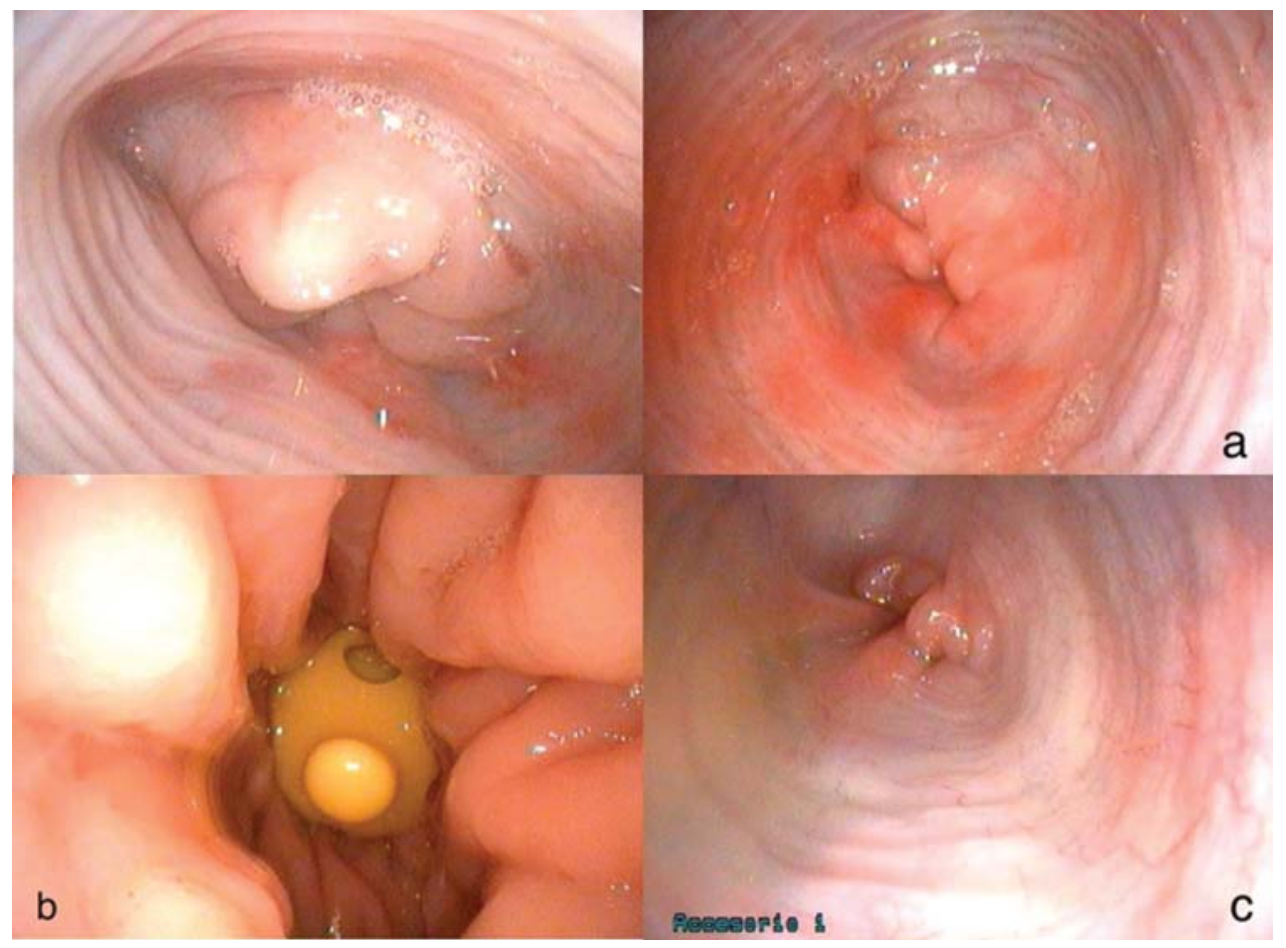

Figure 3. Endoscopic views: (Top left) Imaging of the caudal esophagus, note the dilatation compatible with megaesophagus, esophagitis and obstruction by an intraluminal soft tissue mass identified as the gastric mucosa; (a) Image of the caudal esophagus with the gastroesophageal sphincter closed immediately after gastropexy, note the evident esophagitis; (b) image of the gastric mucosa and the mushroom of the Pezzer catheter between the rugal folds; and (c) aspect of the caudal esophagus a month after gastropexy.

Two weeks later, the patient had recovered weight and body condition. Moreover, the gastropexy tube was in position and working so the patient was discharged with cisapride and a gradual change in the therapeutic diet to a normal dry diet for kittens five meals per day. One month later, esophagogastroscopy showed a normal esophagus with a closed gastroesophageal sphincter and a normal stomach (Figure 3c); the gastropexy tube was removed without complications and cisapride was suspended. Fifteen days after the skin wound from the gastropexy tube had closed completely; and a thoracic survey radiograph was performed showing an evident normal appearance (Figure 5). 


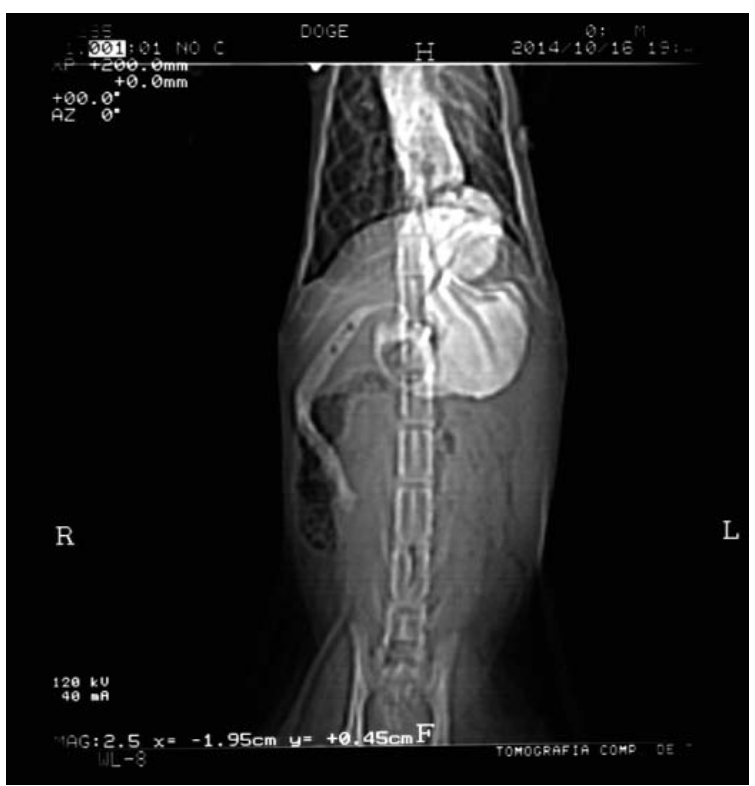

Figure 4. Computed tomography scanning imaging with contrast. The dorsal plane of the thoracoabdominal section shows a detailed diagnostic image of GEI, without evidence of intussusception of other abdominal anatomical structures.
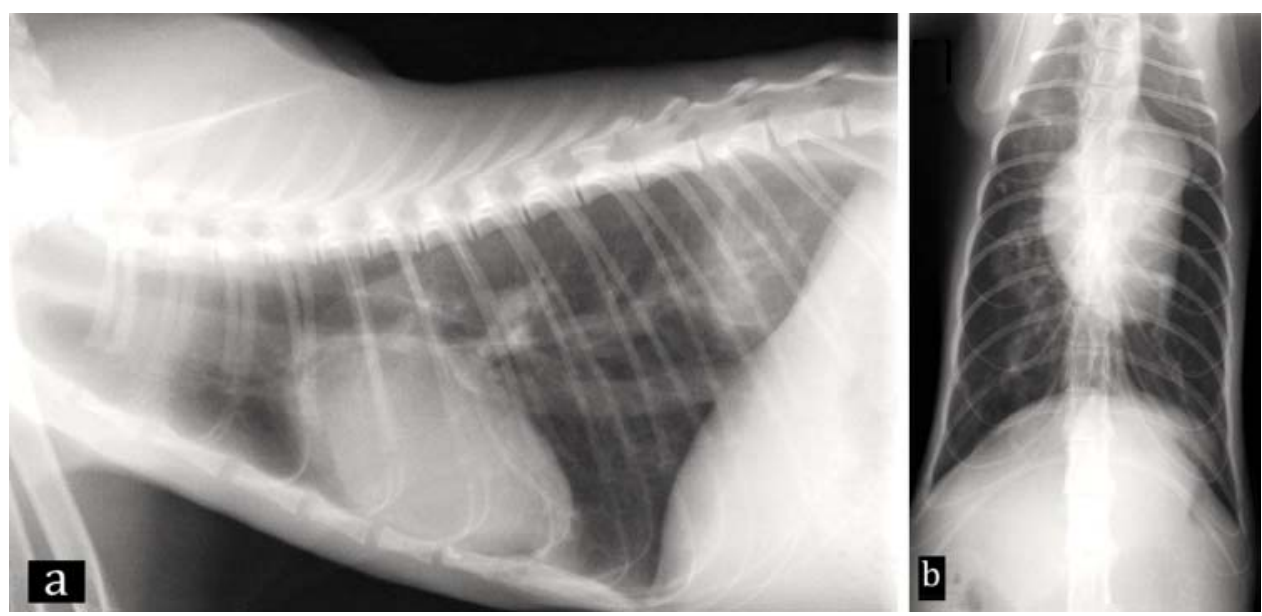

Figure 5. Thoracic survey radiography $(\mathrm{a}, \mathrm{b})$ two weeks after removal the percutaneous gastropexy tube without evidence of recurrence of GEI.

A year later, the patient had grown to a weight of $2.9 \mathrm{~kg}$ and a body condition score of $3 / 5$ and according with the owners the patient was eating small portions of the diet several times a day and was healthy. In eighteen months of follow up the patient has not shown recurrence of signs of GEI.

GEI has been rarely reported in animal species such as the dog [10,11], cat [4-8], leopard (Panthera pardus) [12], cheetah (Acinonyx jubatus) [9] and hedgehog (Atelerix 
albiventris) [13]. Some authors have categorized GEI as a sliding hiatal hernia as it is defined as a transposition of the abdominal part of the esophagus, gastroesophageal junction and a portion of stomach through the esophageal hiatus of the diaphragm $[10,11]$; however, this is different than GEI because the gastroesophageal junction does not move cranially into the thorax $[7,10]$. Occasionally, the spleen, duodenum, pancreas, and omentum may be trapped within the invagination [10].

In the different affected species, the pathogenesis of GEI is not well understood, although it is likely multifactorial. Some authors have suggested a relation with diverse esophageal abnormalities such as megaesophagus $[8,10,12]$, incompetence of the lower esophageal sphincter which often occurs secondary to sliding hiatal hernias, different causes of increased intrabdominal pressure such as chronic vomiting or blunt trauma, and negative intrathoracic pressure from inspiratory dyspnea due to chronic upper airway obstruction or severe respiratory disease [6,10].

On the principal international scientific databases, there are only five clinical cases of GEI in domestic cats reported between 1998 to 2015 in domestic shorthair cats $[5,7,8]$, in a Himalayan [4] and in a Birman [6], including four males and one female; two were kittens, two adults and the last an elder cat, age ranged from 4 months to 15 years old. The clinical cases presented different clinical signs referring to gastrointestinal symptoms such as vomitus or regurgitation [6-8] or respiratory disease such as respiratory distress, open-mouth breathing, inspiratory stridor and mucopurulent nasal discharge, with acute or intermittent presentation $[4,8]$. A clinical case of GEI has been described associated with chronic intermittent vomiting secondary to a hiatal hernia and the presence of a trichobezoar impacted in the GEI [6], secondary to a diaphragmatic hernia [4]. In another clinical case GEI was suggested as a cause of secondary nutritional hyperparathyroidism, justified by hypocalcemia resulting in muscular malfunction and weakness [8]; however, this last association was not conclusively demonstrated. Other unspecific signs included abdominal discomfort on palpation, weight loss, anorexia, hypersalivation, dehydration, depression and crying [6]. The clinical manifestation may improve spontaneously with conservative medical therapy and usually progresses and culminates in death due to respiratory or vascular compromise [5].

In our patient, the intermittent respiratory distress, cyanosis, syncope and abdominal discomfort were associated with intermittent GEI secondary to megaesophagus. According to Moses et al. [2], 45\% of esophageal motility dysfunction cases are associated with the clinical signs of respiratory tract disease.

The diagnostic approach should start with thorax radiography and a positive contrast esophagogram, followed by a definitive diagnosis using esophagogastroscopy [9].

In the previous five cases reported in cats, there were different experiences with the management of this pathology: two were euthanatized due to a deteriorated condition $[6,8]$, one suffered cardiac arrest after open surgery [4], one survived after surgical reduction [5] and one case responded to medical therapy [7]. The mortality of GEI is 
high, in part due to failure to recognize the condition early and the rapid deterioration of the animal without treatment.

Historically, the management for GEI has involved laparotomy by reduction of the intussusception and gastropexy in domestic cats [4,5,] and leopard [12]. Potential disadvantages include a prolonged surgical procedure, hemodynamically compromised patients, an extended convalescence period and possible post-surgical complications. In addition to potential congenital esophageal abnormalities resulting in a guarded prognosis, this may influence the decision leading to euthanasia of a patient with a potentially controllable condition [11].

The use of endoscopic percutaneous gastropexy for the treatment of GEI in dogs was reported in two clinical cases with good results [10,11]. The placement of a percutaneous gastropexy is a simple procedure, which can be performed using endoscopy [14,15] or a gastrostomy tube device [16].

According to different authors, the benefits of percutaneous tube gastropexy include: being a minimally invasive procedure as it minimizes the number and size of surgical incisions, with a shorter anesthesia procedure; and less degree of postoperative pain and requirements for analgesia; incidence of incision complications, days of hospitalization, and cost [15]; and also the possibility of enteral nutrition [10,11]. However, a relative disadvantage is the limitation of to do only a unilateral gastropexy (left-side); contraindications of performing a percutaneous gastropexy for this case would include situations where the gastric wall is compromised or adhesions are formed, which increase the risk of gastric perforation, other limitation is that the assessment and correction of esophageal hiatal abnormalities is not possible with this method $[10,11]$.

GEI in the cat is a rare pathology associated with esophageal dysmotility associated at megaesophagus or hiatal hernia, and should be considered as a differential diagnosis in patients with chronic vomiting, regurgitation or respiratory disease. Survey and contrasted thoracic radiographs can be used to identify gross anatomical abnormalities, but the definitive diagnostic should be made by esophagogastroscopy with the possibility of reducing the GEI, and with the experience in this clinical case described the use of percutaneous gastropexy provides an other possible option to conventional laparotomy to prevent recurrence of this kind of intussusception in cats.

\section{Acknowledgments}

Paolo Cesar Alvarez-Contreras held a scholarship from the Consejo Nacional de Ciencia y Tecnología (CONACyT), Mexico. Authors would like thank to Dr. Celene Salgado Miranda and Dr. Edgardo Soriano Vargas for technical assistance. 


\section{Authors' contributions}

DAC diagnostic, medical and surgical handling of the patient and have been involved in drafting the manuscript of revising it critically for important intellectual content, $\mathrm{BM}$ diagnostic, medical and surgical handling of the patient and have made substantial contributions to conception and design, QH have made substantial contributions to conception and design, AC postsurgical handling of the patient. All authors read and approved the final manuscript.

\section{Declaration of conflicting interests}

The author(s) declared no potential conflicts of interest with respect to the research, authorship, and/or publication of this article.

\section{REFERENCES}

1. Frowde PE, Battersby IA, Whitley NT, Elwood CM: Oesophageal disease in 33 cats. J Fel Med Surg 2011,13:564-569.

2. Moses L, Harpster NK, Beck KA, L Hartzband: Esophageal motility dysfunction in cats: A study of 44 cases. J Am Anim Hosp Assoc 2000,36:309-3012.

3. Levine JS, Pollard RE, Marks SL: Contrast videofluoroscopic assessment of dysphagic cats. Vet Radiol Ultrasound 2014,55:465-471.

4. Van Camp S, Love NE, Kumaresan S: Radiographic diagnosis-gastroesophageal intussusception in a cat. Vet Radiol Ultrasound 1998,39:190-192.

5. Martínez NI, Cook W, Troy GC, Waldron D: Intermittent gastroesophageal intussusception in a cat with idiopathic megaesophagus. J Am Anim Hosp Assoc 2001,37:234-237.

6. Owen MC, Morris PJ, Bateman RS: Concurrent gastro-oesophageal intussusception, trichobezoar and hiatal hernia in a cat. New Zealand Vet J 2005,53:371-374.

7. van Geffen C, Saunders JH, Vandevelde B, Van Ham L, Hoybergs Y, Daminet S: Idiopathic megaesophagus and intermittent gastro-oesophageal intussusception in a cat. J Small Anim Pract 2006,47:471-475.

8. Abbaszadeh Hasiri M, Shojaee Tabrizi A, Ahrari Khafi MS: Gastroesophageal intussusception in a domestic short-hair cat. Iranian J Vet Res-Shiraz University 2013,14:358-361.

9. Sherding RG, Johnson SE. Esophagoscopy. In: Tams TR and Rawlings CA, eds. Small animal endoscopy. $3^{\text {rd }}$ ed. St. Louis, Missouri: Elsevier-Mosby; 2011,41-95.

10. McGill SE, Lenard ZM, See AM, Irwin PJ: Nonsurgical treatment of gastroesophageal intussusception in a puppy. J Am Anim Hosp Assoc 2009,45:185-190.

11. Shibly S, Karl S, Hittmair KM, Hirt RA: Acute gastroesophageal intussusception in a juvenile Australian shepherd dog: endoscopic treatment and long-term follow-up. BMC Vet Res 2014;10:109. DOI: 10.1186/1746-6148-10-109.

12. Hettlich BF, Hobson HP, Snakard EP, Johnson JH: Gastroesophageal intussusception in a leopard (Panthera pardus). J Zoo Wildlife Med 2010,41:519-521 
13. Lee SY, Park HM: Gastroesophageal intussusception with megaesophagus in a hedgehog (Atelerix albiventris). J Exotic Pet Med 2012,21:168-171.

14. Whittemore J, Bartges JW. Endoscopic placement of gastrostomy and jejunostomy tubes. In: Tams TR, Rawlings CA, eds. Small animal endoscopy. $3^{\text {rd }}$ ed. St. Louis, Missouri: Elsevier-Mosby; 2011,311-330.

15. Arican M, Parlak K, İnce E, Güzelbekteş H: Result of endoscopically assisted gastropexy in dogs. Acta Vet-Beograd 2014, 64:226-235.

16. Fossum TW, Hedlund CS, Jhnson AL, et al. Postoperative care of the surgical patient. In: Fossum TW, Hedlund CS, Jhnson AL, et al., eds. Small animal surgery $3^{\text {rd }}$ ed. St. Louis, Missouri: Elsevier-Mosby; 2007, 90-110.

\title{
LEČENJE INTERMITENTNE GASTROEZOFAGEALNE INTUSUSCEPCIJE KOD MAČETA PERKUTANOM GASTROPEKSIJOM
}

\author{
DEL-ANGEL-CARAZA Javier, ALVAREZ-CONTRERAS Paolo Cesar, \\ BARBOSA-MIRELES Marco Antonio, QUIJANO-HERNÁNDEZ Israel Alejandro
}

Gastroezofagealna intususcepcija je retka patološka pojava koju karakteriše akutna ili intermitentna invaginacija želuca u lumen kaudalno od torakalnog dela jednjaka, čija patogeneza nije još uvek u potpunosti razjašnjena, iako je najverovatnije multifaktorijalna. Mortalitet je visok što je najčešće u vezi sa kasnom dijagnozom i brzim pogoršanjem. Kratkodlako muško mače starosti 4 meseca dovedeno je radi povremenog otežanog disanja i bolova u abdomenu tokom protekle 2 sedmice. Na osnovu kliničke anamneze, kliničkih znakova, kao i imidžing dijagnostike postavljena je dijagnoza gastroezofagealne intususcepcije. Smanjenje obima intususcepcije je obavljeno endoskopskom tehnikom uz medikamentoznu i potpornu terapiju. Međutim, postupak nije imao pozitivan ishod te je pacijent podvrgnut perkutanoj gastropeksiji kako bi se sprečilo ponavljanje i obezbedio dugotrajan pozitivan ishod. Gastroezofagealna intususcepcija kod mačaka je povezana sa megaezofagusom i hijatusnom hernijom i treba je smatrati relevantnom u diferencijalnoj dijagnostici kod pacijenata koji hronično povraćaju, regurgituju ili pokazuju znake respiratorne bolesti. Ispitivanje i kontrasna torakalna radiografija se mogu primeniti u cilju identifikacije značajnijih anatomskih poremećaja, ali definitivna dijagnosa se mora postaviti na osnovu ezofagogastroskopije uz istovremeni pokušaj redukcije intususcepcije. Primena perkutane gastropeksije predstavlja još jednu opciju konvenvencionalnom hirurškom pristupu u cilju rešavanja ove patologije kod mačaka. 